Łowy przeszłości wskazują, że świat i my wywodzimy się z tego samego surowca - z pyłu kosmicznego. Wnikając w genealogię, rozglądamy się za tym, co niezmienne, co nieporównanie trwalsze niż ten ząb sprzed czterech milionów lat, który zabłysnął przed oczami młodego archeologa na pustyni w Etiopii. To tęsknota wieczności. Pragnęlibyśmy też pewności, ale o nią trudno, gdy odwołujemy się do rozumu. Chcielibyśmy wiedzieć: dlaczego? Ale nauka nie odpowiada na takie pytania. Tłumaczy, jak działa Natura, lecz nie dlaczego tak działa. Rozum oświetla nam świat, w którym bytujemy, ale wiara nadaje mu sens. Albowiem ",sens pochodzi jedynie od sacrum, (...) nie mogą go wyprodukować żadne empiryczne poszukiwania".

A. Szczeklik, Nieśmiertelność, s. 60. 



\section{NIEŚMIERTELNOŚĆ KOSMICZNA. NA MARGINESIE POWIEŚCI TOMASZA MANNA WYZNANIA HOCHSZTAPLERA FELIKSA KRULLA}

\section{Kultura i śmierć}

Twórczość literacka Tomasza Manna stanowi rozległą panoramę dziejów europejskiej kultury, w tym ludzkich zmagań ze śmiercią. W tetralogii Józef $i$ jego bracia ${ }^{1}$ pisarz ukazał źródła europejskich pojęć dotyczących śmierci i nieśmiertelności, konfrontując ze sobą świat starożytnego Izraela i Egiptu. Z kolei w powieści Wybraniec ${ }^{2}$ pokazał chrześcijańską koncepcję życia i umierania, zarówno w jej przejawach folklorystycznych, jak i mistycznych. Kryzys idei chrześcijańskich, charakterystyczny zwłaszcza dla świata późnej nowożytności, został przez Manna wielostronnie zobrazowany w powieści Buddenbrookowie $e^{3}$, natomiast doświadczenie skończoności człowieka i próby wypracowania

\footnotetext{
${ }^{1}$ T. Mann, Józefi i jego bracia, przeł. E. Sicińska, Czytelnik, Warszawa 1988.

2 Tenże, Wybraniec, przeł. A. Linke, Czytelnik, Warszawa 1960.

${ }^{3}$ Tenże, Buddenbrookowie: dzieje upadku rodziny, przeł. E. Librowiczowa, Czytelnik, Warszawa 1956. Okres wcześniejszy - przełom późnego średniowieczna i wczesnego renesansu - ukazał Mann w dramacie Florencja (tytuł oryg. Fiorenza: Drei Akte), opublikowanym w roku 1905. Sztuka nie odniosła sukcesu, przychylnie przyjęta została jedynie we Frankfurcie w roku 1907. Por. E. Bahr, Art and Society in Thomas Mann's Early Novellas, [w:] H. Lehnert, E. Wessell (eds.), A Companion to the Works of Thomas Mann, Camden House 2004, s. 63. Akcja dramatu rozgrywa się w kwietniu 1492 roku, ukazując spór umierającego Lorenza de Medici z Savonarolą. Wprawdzie
} 
nowej wizji nieśmiertelności (głównie opartej na spirytyzmie) znalazły swój artystyczny wyraz w Czarodziejskiej górze ${ }^{4}$. Niemożliwość pokonania śmierci, rodząca poczucie absurdu, została najpełniej zobrazowana w noweli Śmierć $w$ Wenecji $i^{5}$ oraz w powieści Doktor Faustus ${ }^{6}$, ukazującej zagładę cywilizacji zachodniej, przejawiającą się w powstaniu zbrodniczych ideologii oraz dwóch wojnach światowych. Pomimo tego pesymistycznego obrazu ludzkiego losu, w twórczości Manna znajdujemy wyraz nadziei, że śmierć nie oznacza absurdu, lecz raczej okazję do nadania naszemu życiu wiecznego sensu. Świadczy o tym nieśmiertelność $w$ kulturze, zobrazowana na przykładzie twórczości Goethego w powieści Lotta $w$ Weimarze ${ }^{7}$. Dzieje tytułowej bohaterki sugerują, że człowiekowi dostępna jest nieśmiertelność w postaci literackiego mitu; wprawdzie rzeczywista Lotta musi umrzeć, jednak Lotta jako postać literacka (ukochana Wertera) stała się nieśmiertelna ${ }^{8}$. Inny rodzaj wieczności - nieśmiertelność w kosmosie - została zarysowana w powieści Wyznania hochsztaplera Feliksa Krulla9; niniejszy artykuł stanowi próbę rekonstrukcji owej idei.

\section{Wcielenia Feliksa Krulla}

Idei nieśmiertelności kosmicznej można także upatrywać w powieści Doktor Faustus, zwłaszcza w partiach komentujących muzykę Adriana Leverkühna, wyrażającą nieskończoną i wieczną potęgę wszechświata; jest to jednak kosmos nihilistyczny, znajdujący się w mocy zła i budzący grozę. Optymistyczną wizję nieśmiertelności kosmicznej (czy raczej - człowieka w kosmosie) znajdujemy w powieści Wyznania hochsztaplera Feliksa Krulla, która budzi nadzieję, że każdy człowiek - przez sam fakt zaistnienia na ziemi

Lorenzo nakazał aresztować Savonarolę, widząc w nim zagrożenie dla miasta, tłum uwolnił jednak charyzmatycznego zakonnika; mimo to Savonarola przewidywał już własną śmierć na stosie, mówiąc, że kocha ogień. Por. tamże, s. 63-64. Dramat z jednej strony ukazuje śmierć jako męczeństwo, z drugiej - jako narzędzie działań politycznych. Sam Mann uznał sztukę za nieudaną. Por. C. Koelb, „Death in Venice”, [w:] H. Lehnert, E. Wessell (eds.), Art and Society..., dz. cyt., s. 95.

${ }^{4}$ Nie brak głosów, że Czarodziejska góra stanowi wyraz nadziei na życie wieczne. Por. S. Judycki, Czas i wieczność. Przestanie „Czarodziejskiej góry” Tomasza Manna, [w:] A. Głąb (red.), Filozofia i literatura. Antologia tekstów, Wydawnictwo Naukowe "Semper”, Warszawa 2011, s. 141.

${ }^{5}$ T. Mann, Śmierć w Wenecji, przeł. L. Staff, [w:] tenże, Śmierć w Wenecji i inne opowiadania, Wydawnictwo Dolnośląskie, Wrocław 2003.

6 Tenże, Doktor Faustus, przeł. M. Kurecka, W. Wirpsza, Czytelnik, Warszawa 1960.

7 Tenże, Lotta w Weimarze, przeł. F. Konopka, Czytelnik, Warszawa 1983.

8 Szerzej na ten temat pisałem $\mathrm{w}$ artykule Nieśmiertelność w kulturze. Uwagi na marginesie powieści Thomasa Manna „Lotta w Weimarze”, [w:] H. Jakuszko, L. Kopciuch (red.), Człowiek w kontekstach kulturowych i historycznych, Wydawnictwo UMCS, Lublin 2012, s. 63-85.

9 T. Mann, Wyznania hochsztaplera Feliksa Krulla, przeł. A. Rybicki, Ludowa Spółdzielnia Wydawnicza, Olsztyn 1987. 
- dostąpi wieczności, nadającej sens życiu i usprawiedliwiającej nieuchronny fakt śmierci. Powieść ta jest wyjątkowa w dorobku Manna; zaczął ją pisać w latach 1911-1913 ${ }^{10}$, ukończył zaś prawie czterdzieści lat później, po powrocie z USA do Europy w roku 1952, czyli na trzy lata przed śmiercią ${ }^{11}$. Książkę można zatem uznać za wyraz trwałych przeświadczeń filozoficznych pisarza, a nawet za swoisty testament ideowy i artystyczny. Mimo to sprawia ona wrażenie nieukończonej, co było prawdopodobnie świadomą decyzją autora, ponieważ historia opowiedziana w powieści oraz cechy głównego bohatera wykluczały możliwość finału. Jest to zatem dzieło otwarte, którego sens zależy od inwencji i wyobraźni czytelników. Brak doprowadzenia fabuły do końca i rozwikłania losów bohatera to sposób wyrażenia ludzkiej egzystencji, będącej zawsze niedokończonym projektem, pozbawionym ostatecznego spełnienia. Na przykładzie biografii Feliksa Krulla, Mann ukazuje możliwość nieskończonych przemian osobowości i ról życiowych, rodzących nadzieję na przezwyciężenie śmierci i osiągnięcie nieśmiertelności.

Jedną z głównych cech Feliksa jest niezwykła umiejętność dokładnego przyswajania sobie wiedzy z dziedzin, których wcześniej nie znał. Raz usłyszawszy specjalistyczny wykład na temat pochodzenia życia czy struktury materii nieożywionej, potrafił go z pamięci powtórzyć po wielu latach. Feliks nie był jednak człowiekiem twórczym, zdolnym do samodzielnego operowania zdobytą wiedzą; na kartach powieści jedynie powtarza teorie zasłyszane. Był zatem - zgodnie z tytułem powieści - hochsztaplerem; jego wiedza to typowe nagromadzenie informacji encyklopedycznych, niestanowiące mądrości, czego nie można powiedzieć o erudycji Tomasza Manna, którego zdolność do operowania materiałem z różnych dziedzin zdradzała umysł samodzielny, wnikliwy i twórczy.

Nieprzeciętną pamięć Feliksa Krulla można jednak postrzegać pozytywnie, nie jako powierzchowne nagromadzenie informacji, lecz jako istotny wymiar osobowości bohatera, będącego zwierciadłem wszechświata. Przywołując ontologię Leibniza można powiedzieć, że Feliks to konkretna monada, stanowiąca odbicie świata. Wprawdzie w każdej monadzie odzwierciedla się cały wszechświat, dokonuje się to jednak zawsze w sposób indywidualny i niepowtarzalny. Nie wszystkie też monady są świadome swej funkcji odzwierciedlania, wiele bowiem pozostaje na zawsze w stanie uśpienia. Feliks Krull tymczasem jest monadą o wysokim stopniu świadomości i samoświadomości, zdolną do uprzytomnienia sobie szerokiego zakresu treści przedmiotowych. Rozmowa z innymi była zatem dla niego nie źródłem wiedzy,

${ }^{10}$ H. Lehnert, Introduction, [w:] H. Lehnert, E. Wessell (eds.), Art and Society..., dz. cyt., s. 10.

11 H. Bloom (ed.), Thomas Mann, Chelsea House Publishers 2003, s. 14, 89. Powieść została opublikowana rok przed śmiercią Manna. 
lecz jedynie impulsem do odkrycia zjawisk, których istnienia wcześniej nie przeczuwał. Byłby on zatem również ilustracją Platońskiej teorii anamnezy, głoszącej, że ludzki umysł ma wiedzę wrodzoną, którą jest sobie w stanie uświadomić, o ile zaistnieją sprzyjające okoliczności (w postaci percepcji zmysłowej lub dobrego nauczyciela).

Feliksa Krulla można też potraktować jako everymana - zarówno z racji pochodzenia, jak i cech osobowości. Chociaż przyszedł na świat w rodzinie mieszczańskiej (jego ojciec był właścicielem firmy produkującej wino), to jednak wśród jego przodków było wielu artystów ${ }^{12}$. Urodził się wkrótce po powstaniu cesarstwa niemieckiego, w pobliżu Renu, niedaleko Moguncji, jako potomek Niemców i Francuzów (s. 8) ${ }^{13}$. Już jako dziecko przejawiał talenty aktorskie, bawiąc się w cesarza a nawet wierząc, że nim jest: „(...) nosząc jeszcze dziecinną sukienkę odgrywałem chętnie rolę cesarza i (...) przez wiele godzin trwałem nader uporczywie w tym złudzeniu" (s. 13). Ponieważ nigdy z tej dziecięcej psychiki nie wyrósł, żyjąc wielokrotnie życiem innych ludzi, można go potraktować jako człowieka zdolnego stać się każdym, co ujawniło się chociażby w zdolności doskonałego naśladowania cudzego pisma. Umówiwszy się z przyjacielem, że będzie odgrywać jego rolę, czynił to na tyle dobrze, że nawet rodzice młodzieńca nie rozpoznali kłamstwa; nie zaskoczyła ich ani treść wysyłanych przez niego własnoręcznych listów, ani charakter pisma ${ }^{14}$. Sam Feliks zresztą do tego stopnia potrafił wcielić się w cudzą postać, że bycie synem nieznanych sobie rodziców przeżywał autentycznie jako własny los; nie tylko odgrywał rolę innej osoby jak aktor, lecz dosłownie nią był. Miał zatem osobowość niezwykle bogatą, zdolną do bycia każdym, dzięki czemu bez trudu zmieniał nazwisko i biografię, wcielając się w postacie wielu osób.

Jakże bywa to nużące i nudne wlec przez całe życie ten sam zawsze podpis u spodu listów i aktów! Dłoń drętwieje w końcu przy tym ze wstrętu i przesytu! Jakimże dobrodziejstwem, jaką podnietą, jakim odświeżeniem ludzkiej istoty bywa to, że słyszysz, jak cię przedstawiają i przemawiają do ciebie pod nowym nazwiskiem! (s. 53).

12 T. Mann, Wyznania hochsztaplera Feliksa Krulla, dz. cyt., s. 7-9. Odtąd powieść tę będę cytował przez podanie numeru stronicy bezpośrednio w tekście.

13 To wskazuje na podobieństwo między Krullem a Mannem, który podkreślał, że po ojcu odziedziczył mentalności kupiecką, po matce zaś - będącej z pochodzenia Brazylijką - wrażliwość artystyczną. H. Kurzke, Tomasz Mann - życie jako dzieło sztuki, Wydawnictwo Książkowe Twój Styl, Warszawa 2005, s. 5, 20.

${ }^{14}$ Umowa ta była dla jego przyjaciela koniecznością, związał się bowiem z kobietą, której nie akceptowali jego rodzice. $Z$ tego powodu wysłali go w roczną podróż dookoła świata, aby o swoim romansie zapomniał. Młodzieniec jednak przechytrzył rodziców, nakłaniając Feliksa, żeby pojechał w podróż zamiast niego, dzięki czemu sam mógł spędzać czas z kochanką. Finału umowy nie znamy, ponieważ Mann tego wątku nie kontynuował. Mimo to można wnioskować pośrednio, że oszustwo wyszło na jaw, bądź też, że jeden z młodzieńców nie dotrzymał umowy. Być może nawet Krull nie wsiadł na statek, zatrzymując się w Lizbonie z powodu nawiązanego romansu; już bowiem jako starzec wspominał o swoim pobycie w więzieniu. Jest jednak również możliwe, że powodem kary było inne z licznych oszustw, jakich dopuścił się Feliks. 
Ta zmienność losów oznaczała dla Krulla swoistą reinkarnację. Zmienić wszak dane osobowe, wcielając się w postać innej osoby, to przejąć także jej przeszłość i przyszłość, bagaż jej dotychczasowych doświadczeń oraz projekty i zadania. Zmiana nazwiska nie oznacza przy tym śmierci dawnego ja, ani narodzin nowego, lecz zwielokrotnienie jego życia w innej postaci. Nowy los to dla Feliksa intensyfikacja własnej egzystencji, która w ten sposób zyskuje wymiar nieskończoności, przynajmniej częściowo urzeczywistniając pragnienie bycia zawsze i wszystkim.

Takiej interpretacji losów Krulla nie przeczy fakt, że niektóre z jego zachowań wskazują na hedonistyczny stosunek do życia. Urodzony w majową niedzielę, niechętnie przyszedł na świat, nie pomagając matce w czasie porodu (s. 11). Odkąd jednak znalazł się na świecie, pokochał go namiętnie, do tego stopnia, że na starość niemal wyzbył się potrzeby snu, chcąc maksymalnie wydłużyć świadomość swego istnienia (s. 11-12) ${ }^{15}$. W ciągu całego życia towarzyszyło mu poczucie własnej wyjątkowości oraz przekonanie, że został stworzony do szczęścia. „Tak, wiara w moje szczęście i w to, że jestem beniaminkiem nieba, żyła zawsze $\mathrm{w}$ najgłębszym mym wnętrzu i mogę zapewnić, że na ogół w wierze tej nie doznałem zawodu" (s. 12). Dążenie do szczęścia (rozumianego jako doznawanie przyjemności) było cechą domu, w którym się wychował; jego ojciec wydawał frywolne przyjęcia (s. 17-19), nie mając w sobie nic z zapobiegliwości i pracowitości kupców Lubeki (rodzinnego miasta Manna, sportretowanego w powieści Buddenbrookowie). Nawet przewidywany upadek firmy nie zmienił stylu życia rodziny, żądnej zabawy i luksusu.

Hedonizm Feliksa był jednak specyficzny; nie oznaczał ślepego dążenia do zmysłowych rozkoszy, lecz reakcję na absurd życia, nieuchronnie zmierzającego ku śmierci. Skoro bowiem istnienie nie ma sensu, trzeba potraktować je jako zabawę lub grę. Nie jest to jednak ani chęć stłumienia świadomości absurdu, ani próba obrócenia własnego życia w nic nieznaczący żart. Życie Feliksa to raczej heroiczny wysiłek zapełnienia pustki istnienia i nadania mu wagi, której samo w sobie nie ma; jest to więc próba osiągnięcia nieśmiertelności własnym wysiłkiem, chociażby przez przeżywanie cudzych losów. W przeciwieństwie zatem do bohaterów Lotty w Weimerze, Krull nie wybiera nieśmiertelności w sztuce, lecz wieczność dostępną w aktualnym przeżyciu. Sztuka to według niego tworzenie iluzji sensu, przyjemność tymczasem jest realna przynajmniej $\mathrm{w}$ chwili, w której jej doznajemy, nawet jeśli nie pozostanie z niej żaden ślad w kulturze. Zamiast wieczności sztuki zatem, która jest bardziej szatańską pokusą, niż rzeczywistą obietnicą nieśmiertelności (o czym przekonuje los Adriana Leverkühna uciekającego w obłęd), Feliks obiera postawę ironii, pozwalającą bawić się życiem i szydzić ze śmierci.

${ }^{15}$ W młodości w więzieniu spał lepiej niż na starość na wolności (s. 12). 
Z pewnością nie był on filozofem snującym teorie na temat sensu czy absurdu życia i śmierci. Pod tym względem nie przypomina innych bohaterów Manna; trudno go porównać nie tylko z myślicielami pokroju Leverkühna czy Goethego, lecz także z refleksyjnym Tomaszem Buddenbrookiem czy naiwnym, szukającym wzniosłych idei, Hansem Castorpem. Feliks Krull ujawnia prawdę życia przede wszystkim sposobem swego postępowania.

Człowiek chce być, tak jak jest, oddzielony od innych, chce być sam i w głębi duszy nie chce w ogóle nic wiedzieć o swym bliźnim. Bliźni, ów bliźni, co tkwi w swej własnej skórze, jest dlań, co tu ukrywać, wstrętny, gdyż nie jest wstrętna dlań wyłącznie i najściślej jedna tylko osoba: własna. Tak chce prawo natury; mówię, jak jest. Gdy ktoś zatopiony w myślach siedzi przy stole, gdy opiera łokieć o stól, a głowę na ręku, to kładzie często kilka palców na policzek, a jeden między wargi. Niech tak będzie; to jego palce i jego wargi; ale cóż stąd? To chyba, że trzymać w wargach palec innego człowieka byłoby mu czymś nie do zniesienia, czymś, co budziłoby po prostu wstręt. Czy nie? W ogóle na wstręcie opiera się zasadniczo i z woli natury jego stosunek do innych (s. 359).

Odraza do innych nie jest moralna ${ }^{16}$, lecz estetyczna, w przypadku Feliksa okazuje się jednak wyjątkowo silna, został bowiem obdarzony bardzo wrażliwym zmysłem estetycznym (s. 118).

\section{Doświadczenie śmierci}

Jednym z ważniejszych rysów amorficznej osobowości Krulla był jego stosunek do śmierci postrzeganej jako absurd i zło (s. 109). Może nas ona spotkać nagle, nawet $\mathrm{w}$ chwili najintensywniejszej rozkoszy, co ilustruje zgon wiedeńskiego kupca w ramionach prostytutki (s. 115). Śmierć towarzyszy nam w każdej chwili, czego dowodem jest biologiczny instynkt przetrwania kierujący naszymi zachowaniami; jak bowiem przekonuje obserwacja, ludzie „wegetatywnie kochają, cierpią i trzymają się życia” (s. 118).

Szczególnie dramatycznym doświadczeniem było samobójstwo ojca, mające miejsce $\mathrm{w}$ roku, w którym Feliks ukończył 18. lat (s. 54), symbolicznie wkraczając $w$ dorosłość. Bez skutku próbując ratować upadającą firmę, potem zaś bezskutecznie poszukując nowego zatrudnienia, ojciec Feliksa postanowił rozstać się z życiem (s. 54-56) ${ }^{17}$, chociaż w jego śmierci syn upatrywał także aktu honoru i ofiary dla rodziny.

Lekko biorąc życie i dobroduszny z natury, nie posądzał swych bliźnich o okrutną pedanterię, o odtrącenie go naprawdę od siebie, i z całą niewinnością zaproponował pewnemu miejscowemu towarzystwu akcyjnemu do produkcji win pienistych swą

${ }^{16} \mathrm{Z}$ moralnego punktu widzenia ludzie zasługują na litość (s. 118); litość i współczucie były postulatami formułowanymi przez Artura Schopenhauera, jednego z ulubionych filozofów Tomasza Manna.

17 "(..) przyparty do muru twardością bliźnich, mój biedny ojciec wyzbył się życia" (s. 62-63). 
osobę na stanowisko dyrektora. Odtrącony z szyderstwem, podjął jeszcze sporo prób, by znowu stanąć $\mathrm{w}$ życiu na nogi, po czym niewątpliwie rozpocząłby, i to natychmiast, nową serię uczt i iluminacji. Kiedy wszystko to oczywiście zawiodło, wpadł w rozpacz; a nadto, ponieważ mniemał zapewne, że zagradza tylko nam wszystkim drogę i że bez niego łatwej znajdziemy środki do utrzymania się, postanowił z sobą skończyć (s. 56).

Samobójstwo to było dla wszystkich zaskoczeniem; ojciec zastrzelił się w swoim gabinecie, kiedy rodzina czekała na niego w jadalni. Przerażona córka biegała z wrzaskiem po domu, matka nie była w stanie opuścić jadalni, Feliks zaś przy pomocy służącej Genowefy ułożył zmarłego na kanapie (s. 56-57). Okoliczności te przypominają śmierć Jana Buddenbrooka, który umarł $\mathrm{w}$ fotelu, kiedy rodzina czekała na niego w sąsiednim pomieszczeniu, przygotowana do wyjścia. Wprawdzie Jan nie popełnił samobójstwa, jednak jego śmierć była reakcją na nieuchronny upadek firmy, a także dobrowolnym wycofaniem się z życia oraz ekspiacją za popełnione błędy, zwłaszcza wobec córki Toni, której uniemożliwił małżeństwo z miłości.

Feliks spłacił ojcu „hojnie daninę łez” (s. 57) i zajął się organizacją pogrzebu. Ponieważ jednak Kościół wzdraga się przed samobójstwem (a postępek taki gani również moralność wolna od religii), pojawiły się trudności z pochowaniem ojca w ziemi poświęconej (s. 63) ${ }^{18}$. Ostatecznie jednak ksiądz uznał, że śmierć była efektem wypadku w czasie czyszczenia broni, co pozwoliło na pogrzeb chrześcijański. Mimo religijnej oprawy nie był on okazały, nie uczestniczyli w nim bowiem przyjaciele zmarłego, nie rozumiejąc "obrzędów poważnych, kierujących wzrok ku wieczności" (s. 64).

Śmierć ojca w istotny sposób wpłynęła na losy Feliksa, postrzeganego odtąd jako syn bankruta i samobójcy (s. 66). On sam jednak nie pojmował śmierci $\mathrm{w}$ wymiarze indywidualnym czy społecznym, widząc w niej raczej zjawisko kosmiczne. W podobny sposób pojmował też możliwą nieśmiertelność, ufając, że każdy z nas jest nieusuwalnym elementem wszechświata, niezależnie od tego, gdzie przyszło mu mieszkać.

\section{Symbolika Lizbony}

Akcja powieści w ostatniej fazie dzieje się w Lizbonie, chociaż miasto to było już wcześniej obecne w doświadczeniu głównego bohatera, tu bowiem miał rozpocząć podróż dookoła świata jako inna osoba. Lizbona

${ }^{18}$ Sam Feliks sądził, zjednej strony, że „(...) życie, prawdę mówiąc, nie jest wcale najwyższym z dóbr, którego powinniśmy się dla jego drogocenności zawsze i wszędzie kurczowo trzymać"; z drugiej strony podkreślał, że życie to „ciężkie i twarde zadanie, któremu wytrwale i wiernie podołać jest naszą bezwarunkową powinnością - umknąć przed nim zbyt wcześnie to bezsprzecznie brzydki postępek" (s. 63). To przykład jednej z charakterystycznych dla Krulla sprzeczności. 
nie była zatem celem Krulla, lecz przystanią; mimo to powieść kończy się, gdy Feliks dociera do stolicy Portugalii, postanawiając zostać w niej dłużej $\mathrm{z}$ powodu romansu. Nie wiadomo zatem, czy dotrzymał umowy z bogatym młodzieńcem i czy w ogóle wsiadł na statek. Co ważniejsze jednak, jadąc do Lizbony nocnym pociągiem Krull poznał profesora Katschkę, który wyłożył mu główne teorie kosmologiczne.

Niezależnie od roli Lizbony w powieści Manna, symbolika tego miasta jest szczególna, związana z trzęsieniem ziemi, które miało miejsce 1 listopada 1755 roku $^{19}$. Wydarzenie to, nazywane "filozoficznym trzęsieniem ziemi" ${ }^{\prime 20}$, zburzyło wiarę w racjonalny ład świata. W latach 1756-1757 ukazało się w Europie ponad sto książek i broszur usiłujących wyjaśnić lizbońską tragedię ${ }^{21}$; przede wszystkim poszukiwano odpowiedzi metafizycznych i religijnych, mających wyjaśnić, w jaki sposób kataklizm ów był w ogóle możliwy ${ }^{22}$.

Tragedia Lizbony podważała wiarę w Boga jako wszechmocnego, miłosiernego i opatrznościowego Stwórcę wszechświata, trudno bowiem zrozumieć, jak mógłby (gdyby istniał) do takiego wydarzenia dopuścić. Wyrazicielem takiej postawy był Goethe, przyznając, że - dowiedziawszy się w wieku sześciu lat o trzęsieniu ziemi w Lizbonie - zwątpił w Bożą dobroć ${ }^{3}$.

Niezwykłe (...) wydarzenie światowe po raz pierwszy wstrząsnęło do głębi umysłem chłopca. 1 listopada 1755 roku nastąpiło trzęsienie ziemi w Lizbonie i przejęło grozą cały świat, przywykły już do ciszy i spokoju. Najpotworniejsze nieszczęście dotknęło niespodziewanie wielką, wspaniałą rezydencję, zarazem miasto handlowe i portowe. Ziemia drży i trzęsie się w posadach, morze huczy, zderzają się okręty, walą domy, kościoły i wieże leżą w gruzach, część pałacu królewskiego pochłania morze, rozpadła ziemia zdaje się ziać płomieniem, gdyż wszędy unoszą się z ruin dymy i pożary. Ginie po społu sześćdziesiąt tysięcy ludzi przed chwilą jeszcze spokojnych i zadowolonych, a najszczęśliwszym jest chyba ten, kto nie może już ani odczuć, ani uświadomić sobie swego nieszczęścia. Płomienie szaleją dalej, a razem z nimi szaleje zgraja uwięzionych dotąd, a przez to wydarzenie oswobodzonych zbrodniarzy. Nieszczęśnicy, którzy ocaleli, zdani są na rabunek, mordy i wszelkie zniewagi; tak oto przyroda ze wszech stron objawia swą nieokiełznaną moc. (...) Chłopiec, któremu tyle razy wszystko to opowiadano, niemało był przejęty. Bóg, stwórca i opiekun nieba i ziemi, który jawi mu się w wyznaniu pierwszego artykułu wiary jako mądry i łaskawy ojciec, nie okazał bynajmniej swych ojcowskich uczuć skazując na zagładę zarówno sprawiedliwych,

${ }^{19}$ Por. B. Urbankowski, Myśl romantyczna, Krajowa Agencja Wydawnicza, Warszawa 1979, s. 31 .

${ }^{20}$ Por. B. Baczko, Hiob, mój przyjaciel. Obietnice szczęścia i nieuchronność zła, przeł. J. Niecikowski, M. Kowalska, Wydawnictwo Naukowe PWN, Warszawa 2001, s. 15.

${ }^{21}$ Por. B. Urbankowski, Myśl romantyczna, dz. cyt., s. 33.

${ }^{22}$ Por. B. Baczko, Hiob..., dz. cyt., s. 20.

23 Por. tamże, s. 18-19; B. Urbankowski, Myśl romantyczna, dz. cyt., s. 33. 
jak i niesprawiedliwych. Daremnie młody umysł chłopca starał się bronić przed tymi wrażeniami, tym bardziej że nawet mędrcy i uczeni w Piśmie nie mogli jak należy wyjaśnić zjawiska ${ }^{24}$.

Wbrew opinii Goethego wierzący mogli dowodzić, że ludzie ginący pod gruzami miasta zostali przyjęci do chwały nieba, zwłaszcza, że kataklizm miał miejsce 1 listopada, czyli w dniu upamiętniającym tych zmarłych, którzy dostąpili świętości, chociaż nie zostali oficjalnie kanonizowani przez Kościół ${ }^{25}$. Taka interpretacja wydaje się jednak błędna, z pewnością bowiem nie wszyscy zabici byli sprawiedliwi, zasługując na zbawienie (przynajmniej według kryteriów kanonicznych). Trudno też przyjąć, że Bóg powołuje ludzi do siebie w tak okrutny sposób, skazując ich na śmierć w przerażeniu. Ogrom zniszczeń i grozy przeżytej przez umierających (oraz tych, którzy ocaleli) kazałby raczej widzieć w tym wydarzeniu nadejście czasu ostatecznej rozprawy z siłami zła i sądu nad światem ${ }^{26}$; w gruncie rzeczy jednak również to tłumaczenie nie wytrzymuje krytyki, tragedia lizbońska miała bowiem charakter lokalny. Wprawdzie wkrótce potem trzęsienie ziemi nawiedziło także Genewę, było jednak nieporównanie słabsze; Wolter ironizował, że opłacił je strąceniem tylko jednej butelki wina ze stołu ${ }^{27}$.

Tragedię lizbońską interpretowano też jako karę za grzech. Zdaniem jansenistów i protestantów była ona wyrazem Bożego gniewu za to, że Lizbona stanowiła siedzibę zakonu jezuitów oraz inkwizycji ${ }^{28}$, a jej mieszkańcy skupili się na gromadzeniu wyłącznie dóbr doczesnych (zapominając o wiecznych), bogacąc się zwłaszcza na zamorskim handlu. Hipotezy tej jednak nie da się utrzymać już choćby stąd, że katolicy mogli uważać Lizbonę za miasto szczególnie wierne Bogu; jeśli zaś jej mieszkańcy byli grzesznikami, to nie większymi niż w przypadku innych miast, jak heretycki Amsterdam czy bogaty i pyszny Londyn ${ }^{29}$.

Omawiane wydarzenie było również kłopotliwe dla zwolenników deizmu, przekonanych, że wprawdzie świat został stworzony przez Boga, nie potrzebuje jednak Jego pomocy, działa bowiem według praw gwarantu-

${ }^{24}$ Słowa Goethego cytuję za: B. Baczko, Hiob..., dz. cyt., s. 18-19 (pisownia oryginalna).

${ }^{25}$ W Kościołach wschodnich święto to zaczęto obchodzić w IV wieku, w pierwszą niedzielę po Zesłaniu Ducha Świętego. Na Zachodzie ustanowił je papież Bonifacy IV, poświęcając (13 maja 609 roku) starożytną świątynię ku czci wszystkich bóstw - Matce Bożej i świętym męczennikom. W VIII wieku tytuł ten poszerzono o wszystkich sprawiedliwych, natomiast w roku 835 papież Jan XI ustanowił osobne święto ku czci wszystkich świętych zmarłych, wyznaczając datę jego obchodzenia na 1 listopada. Wszystkich Świętych, [w:] T. Gadacz, B. Milerski (red.), Religia. Encyklopedia PWN, t. 9, Wydawnictwo Naukowe PWN, Warszawa 2003, s. 442.

${ }^{26}$ Tak widział to wydarzenie lud Lizbony. Por. B. Baczko, Hiob..., dz. cyt., s. 19.

${ }^{27}$ Por. tamże, s. 17.

${ }^{28}$ Por. tamże, s. 19.

${ }^{29}$ Por. tamże, s. 20. 
jących mu stabilność; $w$ takim jednak świecie zło nie powinno mieć miejsca. Tragedia lizbońska była niezrozumiała także dla tych deistów, którzy przyznawali, że wszechświat nie jest doskonały. Zgodnie z fizyką Newtona, każdy mechanizm ma wady i wymaga napraw. $Z$ tego powodu twórca nowożytnej mechaniki uważał za konieczne istnienie Boga, który dzięki swej wszechmocy będzie w stanie ułomności świata korygować. Przykładem takiej ingerencji Stwórcy jest korekta ruchu planet, dzięki czemu nie dochodzi do zderzeń między nimi ${ }^{30}$. Przy takim jednak opisie relacji Boga do świata bez odpowiedzi pozostaje pytanie, dlaczego Stwórca nie interweniował $\mathrm{w}$ chwili, gdy Lizbonie groziło trzęsienie ziemi. Znamienna była $\mathrm{w}$ tym względzie sugestia Woltera, zwolennika fizyki Newtona, wierzącego wcześniej, że świat jest racjonalny, a zło możliwe do zniesienia. Już 24 listopada 1755 roku pisał w liście do przyjaciela, że prawa fizyki są raczej okrutne niż racjonalne, zaś w Poemacie o zniszczeniu Lizbony dowodził fałszywości zasady „wszystko jest dobre” ${ }^{31}$. Według Woltera wszechmocny Bóg był w stanie stworzyć świat doskonały (na przykład bez wulkanów, będących dla nas ciągłym zagrożeniem), wykluczając możliwość kataklizmów i nieszczęść; stworzył jednak świat niedoskonały, w którym istnieje nieusuwalne i niesłużące żadnemu dobru - $\mathrm{zło}^{32}$.

Podważając wiarę w ład świata oraz możliwość wyjaśnienia zła, trzęsienie ziemi z 1755 roku zostało powszechnie uznane za kres oświecenia ${ }^{33}$. Lizbona zatem to symboliczne miejsce klęski rozumu wierzącego w nienaruszalny porządek kosmosu ${ }^{34}$, ukazujące znikomość człowieka, którego los nic nie znaczy z perspektywy całości wszechświata. Mimo tego pesymizmu jednak w trzęsieniu ziemi w Lizbonie można dojrzeć także wymiar pozytywny. Jak przekonywał Kant, oznaczało ono zburzenie fundamentów naszego życia i rozumu, nie musi jednak oznaczać zniszczenia podstaw moralności; przeciwnie, powinno raczej wzbudzić w nas miłość do rodzaju ludzkiego.

Zamieszkujemy - pisał Kant w roku 1756 - spokojne terytorium, którego fundamenty ulegają niekiedy zniszczeniu. Beztrosko wznosimy sklepienia, których zworniki chwieją się od czasu do czasu i grożą zawaleniem. (...) Obraz wszystkich nieszczęść, które za sprawą ostatniej katastrofy spadły na inne istoty ludzkie, powinien ożywić naszą miłość do rodzaju ludzkiego i sprawić, że odczujemy choćby cząstkę tych doświadczeń, którymi tak okrutnie zostali dotknięci nasi bliźni ${ }^{35}$.

${ }^{30}$ Por. F.C. Copleston, Historia filozofii, t. 5, Od Hobbesa do Hume`a, przeł. J. Pasek, P. Józefowicz, Instytut Wydawniczy PAX, Warszawa 2005, s. 135.

${ }^{31}$ Por. B. Urbankowski, Myśl romantyczna, dz. cyt., s. 32.

32 Por. Baczko, Hiob..., dz. cyt., s. 15-16, 49.

${ }^{33}$ Por. B. Urbankowski, Myśl romantyczna, dz. cyt., s. 33.

${ }^{34}$ Por. tamże, s. 31.

35 Słowa Kanta cytuję za: B. Baczko, Hiob..., dz. cyt., s. 20. 
Wydarzenie w Lizbonie każe nam jednak również inaczej spojrzeć na miejsce człowieka we wszechświecie; wprawdzie chcielibyśmy siebie uznać za cel stworzenia, to jednak, zdaniem Kanta, błądzimy w ciemnościach, bezbronni wobec sił, których nie pojmujemy.

Człowiek - pisał królewiecki filozof - został ukształtowany w ten sposób, że chętnie uważa się za jedyny cel boskiego stworzenia, jakby Bóg, ustalając zasady rządzące światem, nic innego nie miał na względzie. (...) Tak oto człowiek błądzi w ciemnościach, gdy chce przeniknąć zamiary przyświecające Bogu, kiedy stwarzał ten świat ${ }^{36}$.

Pomimo wiary w potęgę rozumu, człowiek okazuje się istotą bezradną wobec potęgi przyrody, obojętnej na jego dążenia i zdolnej go zniszczyć. Lizbona zatem to symbol potęgi kosmosu ślepego na ludzkie cierpienia. Wbrew naszej pysze nie jesteśmy celem świata; nie znaczymy więcej, niż inne stworzenia, tak bowiem, jak tysiące robaków umiera codziennie pod naszymi stopami, tak tysiące ludzi ginie $\mathrm{w}$ nawiedzających naszą planetę kataklizmach.

W powieści Manna nie znajdujemy odniesień do lizbońskiego trzęsienia ziemi, jednak znaczenie tego wydarzenia było na tyle ważne $\mathrm{w}$ dziejach, że możemy uznać Lizbonę za symbol kataklizmu i ostatecznej zagłady kosmosu. Z takim wyobrażeniem współgra fakt, że Katschka, profesor uniwersytetu lizbońskiego, snuł przed Krullem wizje unicestwienia bytu. Lizbona doskonale też odpowiada osobowości głównego bohatera, urodzonego wędrowca, jest wszak miastem portowym, stanowiącym istotny węzeł komunikacyjny, łączący Europę z innymi kontynentami. Tak zatem, jak Krull jest portretem każdego człowieka, tak Lizbona symbolizuje całość kosmosu i jego losów.

\section{Kultura wobec śmierci}

Jednym z głównych powodów opowiedzenia się Krulla za nieśmiertelnością kosmiczną było jego przekonanie o iluzoryczności nieśmiertelności kulturowej. O ile bowiem Goethe (jako bohater Lotty w Weimarze) uważał twórczość za formę przezwyciężenia skończoności, o tyle Krull widział w kulturze farsę śmierci; przykładem jest corrida, która z pozoru wydaje się ukazywać wzniosłość i piękno śmierci, w rzeczywistości jednak odsłania jej okrucieństwo.

Według profesora Katschki, Portugalczycy „to ludzie miłujący zwierzęta i nieskłonni do dopuszczenia w tej sprawie jakiej bądź ohydy" (s. 367). Byk przecież, który ginie $\mathrm{w}$ walce na arenie, dostępuje bardziej rycerskiej śmierci,

36 Tamże. 
niż gdyby został zabity w rzeźni (s. 367); zmaganie z torreadorem ukazuje wielkość zwierzęcia walczącego o przetrwanie, czyniąc jego śmierć wzniosłą (s. 374) ${ }^{37}$. Feliks jednak dostrzega w corridzie bezsensowne i okrutne cierpienie zwierząt, zabijanych na arenie ku uciesze gawiedzi; walka byka o życie jest pełna grozy i z góry skazana na przegraną (s. 371). Krull rozumiał też, że corrida to bezskuteczna próba oswojenia śmierci, polegająca na jej estetyzacji; śmierć w walce wszak ma być nie tylko honorowa, lecz także piękna. W rzeczywistości jednak corrida zakłamuje śmierć, czyniąc z niej widowisko. Zatrwożone zwierzę, które chce uniknąć walki, zostaje wyszydzone przez publiczność, torreador zaś, okazując pogardę śmierci, zyskuje sławę (s. 372373); mimo to bardziej autentyczny jest lęk zwierzęcia, niż poza przybierana przez jego zabójcę.

Zdaniem profesora Katschki, corrida stanowi pokłosie pradawnych misteriów religijnych, opartych na kulcie krwi. Ostatecznie wszystkie religie mają charakter ofiarniczy: „nad wszystkimi (...) religijnymi nabożeństwami ludów świata unosi się ciągle opar krwi ofiarnej, krwi bożej" (s. 376). Szczególnie bliski corridzie był rzymski kult,

(...) w którym z wyższej chrześcijańskiej warstwy pojęć zstąpiono nisko, ku czci dla nader krwiożerczego bóstwa - obrządek ten omal nie ubiegł ongiś o włos religii Chrystusa w jej charakterze religii powszechnej, tajemnice jego cieszyły się bowiem wielką popularnością. Neofitów chrzczono tam nie wodą, lecz krwią byka, co może był samym bogiem, jakkolwiek wiódł on z kolei żywot w tym, co krew jego przelał. Miała bowiem ta nauka dla wszystkich swych wyznawców coś nierozerwalnie zespalającego, coś skuwającego na śmierć i życie, a jej misteria opierały się na równości i jedności zabójcy i zabijanego, topora i ofiary, strzały i jej celu... (s. 375).

Niezależnie od słuszności tezy o związku między religiami ofiarniczymi a corridą, historia ludzkości jest niewątpliwym świadectwem urzeczenia śmiercią, czego przykładem są masowe zbrodnie i wojny. Trzeba też przyznać, że dzieje kultury obfitują w wiele prób zakłamania śmierci przez eliminowanie jej tajemnicy bądź uczynienie z niej widowiska. Tej banalizacji i estetyzacji śmierci towarzyszy jednak również odwrotny proces - przeceniania jej znaczenia; śmierć, co pokazuje także corrida, jest traktowana jako wyzwanie moralne, któremu powinniśmy sprostać. W rzeczywistości jednak jest zjawiskiem naturalnym; historia Feliksa Krulla pokazuje, że w za równie naturalną powinniśmy uznać naszą nieśmiertelność.

${ }^{37}$ Analogię między konaniem byka na arenie (bynajmniej heroicznym) a losem człowieka zarysował P.L. Landsberg w książce O sprawach ostatecznych (przeł. B. Kazimierczyk, Instytut Wydawniczy PAX, Warszawa 1967). Por. M.A. Krąpiec, Ja-człowiek. Zarys antropologii filozoficznej, TN KUL, Lublin 1986, s. 393-395. Plastyczne obrazy corridy znajdujemy również w utworach Ernesta Hemingwaya, ukazujących nie tylko kult męskości, lecz także swoistą mistykę krwi. 


\section{Kosmos i śmierć}

Nieśmiertelność w sztuce zależy nie tylko od trwałości fizycznej podstawy dzieła, lecz także od ludzkiej pamięci. Ponieważ jednak kres gatunku ludzkiego wydaje się przesądzony, trudno łudzić się, że ktokolwiek dostąpi nieśmiertelności w dziele sztuki. Sugeruje to, że jedyną możliwą nieśmiertelnością jest wieczność całego wszechświata, którego cząstkę stanowimy. Moja nieśmiertelność polegałaby więc na tym, że w ogóle pojawiłem się na świecie; bez względu na to, jak długo będę żył, moje istnienie nigdy nie zostanie wymazane z dziejów kosmosu.

Zalążki tak pojętej nieśmiertelności wyrażała muzyka Leverkühna, zdecydowanie pełniej jednak zarysował ją hochsztapler Krull. Twórczość Adriana ukazywała bardziej wieczność całego kosmosu niż poszczególnych osób go zamieszkujących, Feliks tymczasem akcentuje wieczność poszczególnych jednostek. Adrian bowiem, mimo dramatycznych cierpień, jakich doznał, sławy, którą osiągnął, czy pychy, z którą walczył, był przede wszystkim artystą skupionym nie na swym indywidualnym ja (które oddał szatanowi), lecz na tworzonym przez siebie dziele. Najgłębsze ja Adriana stanowiło narzędzie wyrażenia prawdy wszechświata, mając bardziej charakter kosmiczny niż osobowy. Feliks tymczasem, niezależnie od wielości swoich wcieleń, przeżywał świat egotycznie. Wiedząc, że jest znikomym i nieuchronnie przemijającym elementem kosmosu, żył wyłącznie własnymi doznaniami, uznając je za jedyną realność; nie interesował go ani los wszechświata, ani prawda całości bytu, lecz własne, empiryczne ja. W tej postawie ujawnia się istotna relacja między człowiekiem a światem. Z jednej bowiem strony każde ludzkie ja jest nic nieznaczącą drobiną w kosmosie, z drugiej - stanowi jego centrum i warunek możliwości. Gdyby bowiem nie istniało żadne ja zdolne sobie uświadomić istnienie kosmosu, to pozostałby on na zawsze w mroku, nie różniąc się niczym od nicości. Nie tylko zatem kosmos jest warunkiem człowieka, lecz także człowiek okazuje się niezbędnym warunkiem kosmosu; wprawdzie bez materii nie jest możliwa świadomość, jednak bez świadomości materia nie zostałaby w ogóle poznana. Świat bowiem jest możliwy o tyle tylko, o ile istnieje świadomy podmiot zdolny do poznania go ${ }^{38}$; zgodnie z przekonaniami Feliksa takim podmiotem jest ja każdego z nas.

${ }^{38}$ Tezy tej broniło, w różnej wersji, wielu filozofów, zwłaszcza Kant, Fichte, Schopenhauer, Husserl czy Wittgenstein. Istotne problemy metafizyczne i epistemologiczne (spór idealizm-realizm czy solipsyzm-pluralizm) związane z tą tezą podjąłem w książce Śmierć, nieśmiertelność, sens życia. Egzystencjalny wymiar filozofii Ludwiga Wittgensteina, Wydawnictwo Aureus, Kraków 2006 (zwłaszcza rozdziały II i VI) oraz w artykule Death is Not an Event in Life: Ludwig Wittgenstein as a Transcendental Idealist, „Idealistic Studies” 2007 / 37, nr 1, s. 51-66. 
W postawach Adriana i Feliksa widzimy dwie różne i wzajemnie do siebie niesprowadzalne perspektywy. Leverkühn usiłował odsłonić prawdę kosmosu z perspektywy absolutnej całości, uwalniając się - na ile to możliwe - od własnej subiektywności; dążył do przezwyciężenia punktu widzenia ja, chcąc osiągnąć widok znikąd ${ }^{39}$. W rezultacie musiał dojść do wniosku, że ludzkie ja nie ma żadnego znaczenia w nieskończonym wszechświecie. Feliks z kolei usiłuje pokazać prawdę jednostki z perspektywy subiektywnej; istnienie każdego ja okazuje się nieskończenie ważne zarówno dla świata (gdyby nie istniał podmiot świadomy świata, to nie istniałby również świat), jak i dla samego siebie. Znaczy to, że każde ja ma prawo sądzić, podobnie jak Krull, że jest ostatecznym warunkiem a zarazem celem bytu, który istnieje wyłącznie dzięki niemu i dla niego.

Wartość jednostki jednak jest nie tylko wartością jej subiektywnych przeżyć; jest także niezbywalna dla charakteru i struktury świata, bez niej bowiem nie byłby on taki, jaki jest. Każde ja (jak również najmniejsza drobina nieświadomej materii) wpływa na kształt i charakter całości, której jest częścią, bez niej bowiem kosmos byłby inny. Jak podkreślali neohegliści (zwłaszcza Josiah Royce oraz Francis Herbert Bradley), wszechświat to system relacji każdej rzeczy z wszystkimi pozostałymi, wobec czego usunięcie jednej zmienia cały system. Znaczy to, że także ja jestem niezbędny dla świata, beze mnie bowiem byłby on innym światem.

Jako konieczny element kosmosu każde ja okazuje się równie wieczne jak kosmos, chociaż nie w sensie trwałego zachowania indywidualnej świadomości, lecz faktu istnienia. Odkąd bowiem pojawiłem się na świecie, moje życie jest faktem wiecznym, tego bowiem, że byłem, nie da się już z dziejów wszechświata usunąć. Warunkiem mojej nieśmiertelności nie jest nawet istnienie Boga jako Absolutnego Umysłu, zdolnego mnie pamiętać także po mojej śmierci, ponieważ sam fakt mojej obecności w świecie jest wieczny. Moje istnienie byłoby wieczne nawet, gdyby wszechświat przestał istnieć. Możliwość taką sugerował profesor Katschka; jego zdaniem, chociaż życie na Ziemi jest odporne na rozmaite zagrożenia, to jednak wydaje się tylko epizodem w dziejach naszej planety i całego kosmosu (s. 268). Podobnie epizodyczny może się okazać sam byt, jako zawieszony między dwiema nicościami. „Nie istniał bowiem byt zawsze i nie zawsze też będzie istniał" (s. 272).

Katschka głosi ontologię antyparmenidejską, w myśl której byt jest przypadkowy i skończony, wyłonił się bowiem z niebytu i do niebytu wróci; wieczna okazuje się tylko nicość (s. 277). Znaczy to, że indywidualne życie ludzkie to tylko powtórzenie w mikroskali przygody całości bytu. Nawet jednak taki scenariusz nie przeczy wieczności mojego ja jako elementu kosmosu;

${ }^{39}$ Wyrażenie „widok znikąd” spopularyzował w filozofii Thomas Nagel. 
skoro zaistniałem, to fakt ten na zawsze należy do dziejów wszechświata ${ }^{40}$. Chociaż byt zostanie unicestwiony, to nie przestanie być faktem, że wcześniej istniał. Realności bytu między nicością poprzedzającą go i nicością następującą po nim nie da się zakwestionować; $w$ tym sensie jest on wieczny. Skoro zaś ja byłem elementem bytu, to również moje istnienie okazuje się wieczne, pomimo przyszłego totalnego unicestwienia. Wprawdzie nie istnieję zawsze, to jednak zawsze jest faktem, że kiedyś istnieję; chociaż nie jestem wieczny, to jednak wieczne jest to, że w ogóle jestem.

Opis ten rodzi problem sensowności użycia kategorii czasowych do opisu bytu po jego unicestwieniu. Skoro nie istnieje nic, to nie ma również czasu, nie można zatem powiedzieć, że po unicestwieniu całości bytu, jest prawdą, że byt istniał wcześniej. Trudność ta dowodzi jednak tylko tego, że nicości nie da się wypowiedzieć, co każe powątpiewać w słuszność hipotezy ostatecznego i totalnego unicestwienia. Jeśli jednak przyjąć, że można sensownie mówić o unicestwieniu bytu, to równie sensowne będzie powiedzieć, że mimo jego unicestwienia nie została zniszczona jego realność w czasie, kiedy istniał. W takim zaś razie także moje istnienie jest wieczne, nie można go bowiem usunąć z dziejów kosmosu. Jest więc prawdą, że jestem zawsze; przed pojawieniem się na świecie istniałem jako przyszłe ja mające się w nim pojawić, po unicestwieniu mnie będę istniał jako przeszłe ja, które wcześniej zamieszkiwało świat. Skoro przeszłość i przyszłość są realne, ja zaś stanowię niezbędny element wszechświata, to byłem nim już także wtedy, zanim się urodziłem; moje przyszłe istnienie było faktem od zawsze. Podobnie po unicestwieniu

40 Ta anty-Parmenidejska ontologia profesora Katschki z perspektywy ludzkiego rozumu może się wydawać sprzecznością, ponieważ nie potrafimy pojąć ani unicestwienia własnego ja, ani unicestwienia świata; wyobrażając sobie nicość, wyobrażamy sobie zarazem istniejący podmiot, co jest sprzeczne. W takim jednak razie za podstawową i naturalną dla ludzkiego umysłu powinniśmy uznać ontologię Parmenidejską, zgodnie z którą byt jest koniecznością, niebyt zaś niemożliwością. Jeśli zaś nawet intelektualna ostrożność kazałaby przyjąć, że wywody Katschki mają pozory słuszności, odwołują się bowiem do możliwego stanu rzeczy (niemożliwość pojęcia nicości nie dowodzi, że unicestwienie podmiotu i świata jest niemożliwe w sensie ontycznym), to i tak należy stwierdzić, że nawet po unicestwieniu świata byłoby wiecznie prawdą jego istnienie wcześniejsze. Za niemożliwością nicości opowiadają się także zwolennicy kreacjonizmu, zdaniem których możliwe jest wprawdzie nieistnienie świata, nie jest jednak możliwe, żeby nie istniało nic; istnieje przynajmniej Bóg jako byt konieczny. Warto dodać, że pewną próbę zobrazowania realności nicości podjął Isaac Bashevis Singer w opowiadaniu Opowieści zza pieca w tomie Przyjaciel Kafki. Została tam opisana historia człowieka, który zniknął w czasie orki na polu, przy czym nie wpadł do rowu, nie zapadł się pod ziemię, nie został porwany przez demony, nie uciekł z inną kobietą ani nie został pożarty przez dzikie zwierzęta; po prostu znikł. Innym przykładem jest drewutnia, która nie spłonęła, nie została rozebrana, zburzona ani spalona; po prostu zniknęła. Por. I.B. Singer, Opowieści zza pieca, [w:] I.B. Singer, Przyjaciel Kafki, przeł. E. Petrajtis-O'Neill, Wydawnictwo MUZA, Warszawa 2004, s. 69-74. W obu wypadkach (pomijając wielowarstwową symbolikę opowiadania) mamy do czynienia z nicością relatywną, to znaczy ze zniknięciem osoby lub rzeczy na tle nadal istniejącego świata. Nie jest to zatem nicość absolutna, o której mówi Katschka. 
mnie będzie wiecznym faktem to, że istniałem w przeszłości. Istnieję przeto wiecznie, zmienia się tylko forma mojego bytowania - może być ono przyszłe, teraźniejsze lub przeszłe.

Tak rozumiana wieczność człowieka jest bardzo ograniczoną formą nieśmiertelności, chociażby z powodu braku możliwości podróżowania w czasie $^{41}$. Skoro nie mam dostępu do przeszłości ani do przyszłości, to moje istnienie nie może być zwielokrotnione; jest jedyne i niepowtarzalne; mimo to nie można go usunąć z dziejów świata. Wprawdzie zatem moja nieśmiertelność jest tylko nieśmiertelnością bytu, którego cząstkę stanowię, jest jednak real$\mathrm{na}^{42}$. Ma ona z pewnością charakter panteistyczny, w wieczności kosmicznej bowiem, oczekiwanej przez Krulla, element indywidualności został usunięty; jestem nieśmiertelny tylko jako element kosmosu, bez jakiejkolwiek świadomości swego istnienia po śmierci. Nieśmiertelność kosmiczna ma jednak charakter uniwersalny, w przeciwieństwie do elitarnej nieśmiertelności w kulturze. O ile według Goethego, jako bohatera Lotty w Weimarze, wieczności mogą dostąpić jedynie nieliczni (ci, których geniusz poety uwieczni w dziele sztuki), o tyle według Krulla dostąpi jej każdy; wprawdzie nie każdy jest artystą ani nie istnieje jako wieczny mit, każdy jednak, kto tylko zaistniał, należy na zawsze do dziejów kosmosu. Nawet, jeśli moje istnienie zostanie całkowicie zapomniane, to jednak zawsze pozostanie prawdą, że byłem.

W podobny sposób nieśmiertelna jest każda najdrobniejsza i nieświadoma cząstka materii; także ona - raz zaistniawszy - jest wiecznym elementem kosmosu. Sugeruje to, że osobowa jaźń nie ma większego znaczenia we wszechświecie, niż nieświadome cząstki materii. Pogląd taki był bliski przekonaniom Einsteina, zdaniem którego ludzka śmierć to zjednoczenie z bez-

${ }^{41}$ We współczesnej filozofii nie brak pomysłów (odwołujących się do Einsteinowskiej idei czterowymiarowej czasoprzestrzeni), w myśl których możliwe jest podróżowanie do przyszłości i przeszłości jako odwiecznie i realnie istniejących segmentów kosmosu. Por. H.S. Silverstein, The Evil of Death, "The Journal of Philosophy” 1980, nr 77, s. 401-424; R. Puccetti, Do the Dead and the Unborn Exist?, „Dialogue. Canadian Philosophical Review” 1988, nr 27, s. 533-537. Szerzej na ten temat pisałem w książce Zagadnienie śmierci w filozofii analitycznej, TN KUL, Lublin 1999, s. 196-200, 203-206.

${ }^{42} \mathrm{~W}$ omawianej powieści Manna pojawia się jeszcze inna perspektywa nieśmiertelności jako regeneracji życia czy nawet wskrzeszania go dzięki technice; ilustruje ją współpracownik Katschki - Hurtado, odtwarzający strukturę zmarłych zwierząt w postaci sztucznych modeli. Według żony profesora Katschki, a także według przekonań samego Hurtado, jest to tylko wstęp do naukowo pojmowanego zmartwychwstania, które będzie możliwe w przyszłości (s. 294). Postulat dosłownego wskrzeszania umarłych głosił rosyjski myśliciel, Nikołaj Fiodorowicz Fiodorow, traktując je jako spełnienie moralnego obowiązku wobec zmarłych, wynikającego z przykazania miłości bliźniego. Por. N.F. Fiodorow, Filozofia wspólnego dzieła, przeł. C. Wodziński, „Kronos” 2009, nr 3 (10), s. 5-44. Wątku tego nie rozwijamy, ponieważ bohaterowie Manna do idei Fiodorowa nie nawiązują, a kontekst ich wypowiedzi nakazuje upatrywać w nich wyraźnej ironii Manna. 
osobową materią wszechświata ${ }^{43}$. Stanowisko to zdawał się podzielać także Krull, uznając pogrzeb swego ojca za zwrócenie ziemi śmiertelnych szczątków zmarłego (s. 68). Każdy człowiek ma istnienie jedynie pożyczone, wyłaniając się z całości na pewien czas, potem zaś nieuchronnie do niej wracając. Taki bieg rzeczy pozwala odczuć jedność z całością wszechświata, czego wyrazem była wola Einsteina, by jego zwłoki skremować, a prochy rozsypać ${ }^{44}$. Śmierć nie oznacza absurdu ani ostatecznego unicestwienia, lecz powrót do całości, czyli odnalezienie i ocalenie najgłębszego wymiaru naszego życia. Wieczne okazuje się nie ja konkretnej osoby, lecz ja powszechnego bytu, wolne od wszelkiego egoizmu.

\section{Wartość nieśmiertelności}

Tak pojęta nieśmiertelność jest faktem oczywistym, oznacza bowiem, że to, co kiedykolwiek istnieje, nie jest wieczną nicością. Można jednak wątpić, czy wieczność ta ma dla człowieka jakikolwiek sens, skoro wieczny jest tylko fakt mojego istnienia, a nie moja świadomość.

W odpowiedzi można stwierdzić, że chociaż każdy z nas żyje jak efemeryda, to jednak fakt naszego istnienia jest realny i nieusuwalny ze świata. Chociaż nie jest nam dana wieczność życia i świadomości, to jednak dzięki pojawieniu się na świecie zaznaliśmy przynajmniej smaku życia. „Lepiej przeżyć choćby jeden wieczór tak jak efemeryda. Tutaj bowiem, to, co długie, i to, co krótkie, równoważy się. Poznałem smak życia. Nawet jeśli mam umrzeć, a jestem na to skazany, przynajmniej mogę powiedzieć, że zaznałem życia" ${ }^{45}$. Podobne przekonania wyrażał Feliks Krull, zdaniem którego życie ma wartość właśnie z racji swej kruchości i przemijania. „Tylko to, co epizodyczne, co ma swój zaczątek i kres, jest zajmujące i wzbudza sympatię, będąc przepojone nietrwałością" (s. 277). Jednorazowość i kruchość życia powoduje, że staje się ono nieskończenie cenne.

Krull sugeruje również, że dostępną nam nieśmiertelność należy pojmować raczej jakościowo, niż ilościowo. Wprawdzie nasze życie świadome trwa tylko przez ograniczony czas, to jednak nawet najkrótszy moment świadomości siebie, jaki może być mi dany, jest swoistym dotknięciem wieczności. Kto zatem przynajmniej raz dostąpił świadomości własnego ja, wie, czym jest bycie i świadomość bycia; znaczy to, że dłuższe trwanie tej świadomości ni-

43 Por. M. Barone, M. Gajewska, Einstein i tajemnica wieczności życia, przeł. K. Hubaczek, „Edukacja Humanistyczna” 2007, nr 1 (16), s. 12.

44 Por. tamże, s. 8.

45 V. Jankélévitch, To, co nieuchronne. Rozmowy o śmierci, przeł. M. Kwaterko, PIW, Warszawa 2005 , s. 35. 
czego istotnie nowego do tego pierwotnego doznania nie dodaje. Wprawdzie mogą się zmieniać treści naszej świadomości, nie zmienia się jednak bycie świadomym siebie. W tym sensie miał rację Marek Aureliusz, gdy pisał, że każdy, kto przeżył jeden dzień, przeżył całe życie, doświadczył wszak narodzin (przebudzenia świadomości) oraz śmierci (zasypiania) ${ }^{46}$.

Idea nieśmiertelności kosmicznej rodzi jednak inny problem, wydaje się bowiem zakładać skrajnie deterministyczną wizję świata. Skoro jeszcze przed moim narodzeniem moje istnienie było już realne - jako przyszłe, to należy przyjąć, że wszystkie zdarzenia prowadzące do mojego zaistnienia były konieczne; to zaś sugeruje, że równie zdeterminowane są wszystkie moje czyny. Wtedy jednak fikcją okazuje się wolność, co zdaje się wskazywać na kolejną sprzeczność w poglądach i życiu Krulla, który właśnie z wolności uczynił naczelną zasadę swej egzystencji.

Trudność tę można próbować ominąć. Jeśli nawet fakty sprzed moich narodzin wyznaczają (i przesądzają) moje pojawienie się na świecie, to nie musi to jeszcze niszczyć mojego wewnętrznego poczucia wolności. Krull zdawał się wszak pojmować wolność jako brak świadomości istnienia czynników, które zakłócałyby jego wolne wybory. Podobnie nie przeżywał swego istnienia jako koniecznego, lecz raczej jako przygodne, którego mogło w ogóle nie być lub być inne. Nawet jeśli było odwiecznie zdeterminowane strukturą kosmosu, nie było takim z perspektywy indywidualnej świadomości samego Feliksa.

Niezależnie jednak od ludzkiego poczucia wolności, kluczowa wydaje się idea możliwości jako fundamentu kosmosu. Przyjmując jej rozumienie Spinozjańskie, zgodnie z którym istnieje tylko to, co jest możliwe, należałoby powiedzieć, że byt, który nie zaistniał, nie był możliwy (zakresy bytu możliwego i rzeczywistego są identyczne). Możliwość nie oznacza jedynie niesprzeczności bytu, lecz dodatkowo spełnienie warunków przyczynowych, dzięki którym może on stać się realny; jeżeli warunki takie nie zachodzą, to dany byt jest wykluczony z istnienia tak samo, jak obiekty sprzeczne (nie jest zatem możliwy). W myśl koncepcji Spinozy, możliwość oznacza współmożliwość z wszystkimi innymi obiektami w świecie jako całości; w gruncie rzeczy jest więc synonimem konieczności wszystkich rzeczy ${ }^{47}$. Wówczas jednak trudno mówić o wolności jako realnej możliwości działania innego niż to,

${ }^{46}$ Markowi Aureliuszowi chodziło to, że jeden dzień jest wystarczająco długi, by doznać przyjemności i przykrości, dobra i zła, rozpaczy i nadziei; jego uwagi można jednak także odnieść do chwilowego przebudzenia świadomości.

${ }^{47}$ Koncepcja ta jest bardzo rozsądna; wprawdzie mogłoby się wydawać, że każdy niesprzeczny stan rzeczy jest możliwy (na przykład ten, że Einstein był synem królowej Elżbiety I), to jednak urzeczywistnienie go wymagałoby niewyobrażalnych zmian $\mathrm{w}$ strukturze świata. Wydaje się zatem sensownym powiedzieć, że taki stan rzeczy w ogóle nie jest możliwy; to natomiast wskazuje na ograniczoną moc argumentacji odwołujących się do eksperymentów myślowych. 
które każdorazowo podejmujemy; moje czyny są możliwe tylko o tyle, o ile współgrają z całością wszystkich pozostałych zdarzeń we wszechświecie. Trzeba jednak podkreślić, że przy takim rozumieniu świata moje ja jako jego element jest rzeczywiście wieczne, ponieważ stanowi niezbędny element wszystkich rzeczy.

Bardziej liberalne rozumienie możliwości (odpowiadające także sensowi potocznemu tego pojęcia) utożsamia ją z niesprzecznością; rzecz jest możliwa, o ile nie zawiera żadnych cech wzajemnie się wykluczających. Gdybyśmy przyjęli dodatkowo, że każda możliwość istnieje obiektywnie, znaczyłoby to, że istnieją wszystkie niesprzeczne stany rzeczy, przynajmniej jako możliwości. Istniałyby zatem takie stany rzeczy, które w świecie aktualnym nie zostały urzeczywistnione, jak chociażby ten, że Tomasz Mann był synem Henryka VIII. Takie jednak rozumienie możliwości od razu rodzi problem tożsamości bytu w różnych światach możliwych; w jednym wszak Mann byłby synem Henryka VIII, w innym jego bratem, w jeszcze zaś innym - ojcem, ponieważ wszystkie te sytuacje są możliwe do pomyślenia jako niesprzeczne. Uwzględniając jednak wszystkie możliwości musielibyśmy przyjąć, że każda możliwa osoba mogłaby przeżyć wszystkie możliwe stany rzeczy, a zatem mogłaby być każdym ${ }^{48}$. Z pewnością byłoby to spełnienie najgłębszych pragnień Krulla, wątpliwe jednak, by mogło zostać zrealizowane w przypadku istoty skończonej; być wszystkim jest możliwe tylko dla absolutu ${ }^{49}$.

Można wreszcie przyjąć rozwiązanie pośrednie (bronione chociażby przez Leibniza), zgodnie z którym możliwe jest wprawdzie to, co niesprzeczne, urzeczywistnione jednak mogą być tylko niektóre stany rzeczy, tworzące wspólnie spójny system (świat). Przy takim rozumieniu zakres możliwości jest szerszy od zakresu bytów rzeczywistych, nasze istnienie zaś okazuje się cudem. Skoro z potencjalnie nieskończenie wielu możliwych osób to właśnie ja dostąpiłem istnienia, fakt ten stanowi albo dzieło przypadku, albo wyboru dokonanego przez Boga ${ }^{50}$. W żadnej jednak z tych sytuacji nie można mówić o determinizmie - ani w odniesieniu do mojego

${ }^{48} \mathrm{Z}$ tego właśnie powodu Borges, który definiował człowieka nieśmiertelnego jako będącego każdym, wykluczał możliwość życia wiecznego. Musiałoby ono oznaczać nieskończony czas, w nieskończonym czasie zaś musiałyby mi przydarzyć się wszystkie możliwe stany rzeczy; znaczy to, że byłbym każdym, co jest absurdem, przynajmniej z perspektywy aktualnej, indywidualnej i skończonej świadomości każdego z nas. Por. J.L. Borges, Nieśmiertelny, przeł. M. Potok-Nycz, [w:] J.L. Borges, Alef, przeł. Z. Chądzyńska, M. Potok-Nycz, Prószyński i S-ka, Warszawa 2003, s. 21.

49 Osobnym problemem jest kwestia tożsamości osoby w różnych światach możliwych, szczegółowo dyskutowana we współczesnej anglosaskiej filozofii analitycznej.

${ }^{50}$ Leibniz uważał, że racją naszego istnienia jest to, że należymy do najdoskonalszego świata; Bóg bowiem jako moralnie doskonały, nie mógł nie podzielić się istnieniem z innymi bytami, stwarzając zaś świat, nie mógł stworzyć innego, niż najdoskonalszy w możliwych. 
zaistnienia, ani do podejmowanych działań. Niezależnie też od tego, czy znalazłem się na świecie $\mathrm{w}$ wyniku przypadku, czy z woli Boga, moje istnienie okazuje się niezwykle cenne i oczywiście wieczne - jako element świata, który faktycznie zaistniał.

Nawet zgadzając się, że idea nieśmiertelności kosmicznej nie przeczy wolności człowieka, można zapytać, czy należy ją w ogóle nazywać nieśmiertelnością. Skoro nie oznacza ona wiecznego trwania mojego świadomego ja, to nazywanie jej nieśmiertelnością wydaje się przesadą. Sprawa komplikuje się dodatkowo z racji ewidentnych różnic ludzkich losów; jedni umierają młodo, doświadczywszy wyłącznie dramatycznych cierpień, inni z kolei w późnej starości, bez bólu i w poczuciu spełnienia. Skoro zaś jednym z istotnych podstaw wiary w życie wieczne jest nadzieja, że będzie ono wyrównaniem krzywd, nieśmiertelność kosmiczną należy odrzucić, ponieważ jest aksjologicznie neutralna, oznaczając jedynie wieczną prawdę o tym, że kiedykolwiek istniałem.

Problem ten jest rzeczywiście trudny do rozwiązania; jeśli człowiek marzy o nieśmiertelności jako wiecznej świadomości siebie samego, to wieczność kosmiczna nie może go zadowolić. Kłopot w tym, że - przynajmniej z perspektywy naszego skończonego doświadczenia - niemożliwe wydaje się stwierdzić, czy jakakolwiek inna nieśmiertelność (zwłaszcza osobowa) jest nam dostępna. Wprawdzie wieczność samego faktu, że aktualnie jestem, może się wydać mało atrakcyjna (zwłaszcza z perspektywy lęku przed śmiercią i pragnienia bycia zawsze), jest jednak najprawdopodobniej jedyną wiecznością realną; nie ulega też wątpliwości, że jest wiecznością dostępną wszystkim, którzy kiedykolwiek żyli w przeszłości, żyją obecnie lub dopiero pojawią się na świecie. Tak rozumiana wieczność ma również istotny aspekt moralny; skoro moje istnienie jest nieusuwalne ze świata, to równie nieusuwalne okazują się wszystkie moje czyny - zarówno szlachetne, jak i haniebne. Sugeruje to, że idea nieśmiertelności kosmicznej zachowuje istotną treść pojęć wiecznej kary i wiecznej nagrody; niezależnie od tego, czy ktokolwiek o naszych działaniach pamięta, będą one na zawsze należeć do historii wszechświata i na zawsze określać nas jako moralnie dobrych lub złych. Wyznawana przez Feliksa Krulla idea wieczności wskazuje też na jedyność życia, które dzięki temu okazuje się nieskończenie cenne. Niezależnie od tego, jaki przybiera kształt, jest każdorazowo życiem czyimś (jakiegoś konkretnego ja), z jego wyjątkowością i niepowtarzalnością. Znaczy to, że powinienem nie tyle oczekiwać dłuższego życia od tego, które jest mi przeznaczone, ile być wdzięcznym losowi za to, że w ogóle zaistniałem. Biorąc bowiem pod uwagę wszystkie okoliczności, które doprowadziły do mojego pojawienia się w świecie, mogłem równie dobrze nigdy nie zaistnieć; wystarczyłoby przecież, żeby jeden element łańcucha przyczynowego prowadzącego do moich narodzin uległ 
zmianie. Prawdziwym cudem zatem nie byłoby wcale to, że - raz urodzeni, nigdy nie podlegalibyśmy śmierci; prawdziwym cudem jest raczej to, że w ogóle pojawiliśmy się na świecie.

Cosmic immortality.

A note on Thomas Mann's novel

Bekenntnisse des Hochstaplers Felix Krull

\section{Summary}

This article presents a philosophical interpretation of Thomas Mann's novel Confessions of Felix Krull, in which the writer presents a very original conception of immortality. According to the main character of the novel, Felix Krull, it is not possible for humans to live after death, but people are, after all, eternal beings, because their existence cannot be eliminated from the history of the world. This means that even if the world ceases to exist in the future, the fact of our existence will remain for eternity because it will always be true that we were once a part of the world and its history. 
